\title{
LIBROS
}

\section{Guía de protocolo y derecho premial civil}

PORTUGAL BUENO, M. a del Carmen, Síntesis, Madrid, 2016. 176 págs.

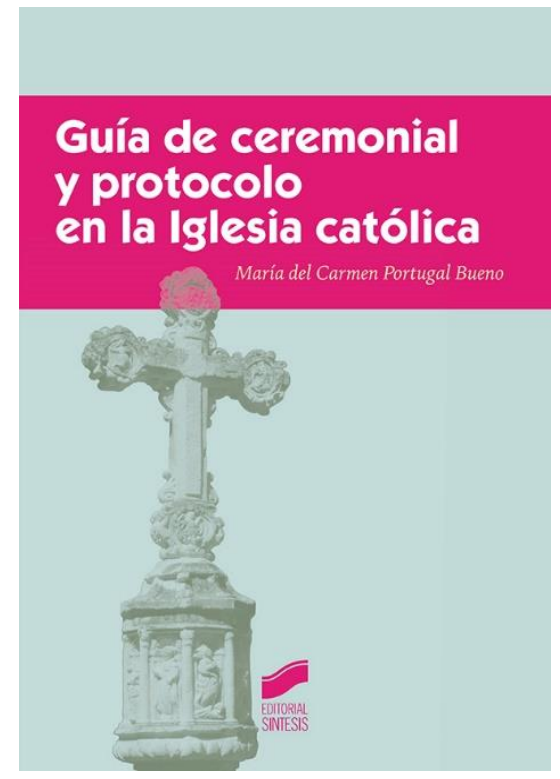

Dolores del Mar Sánchez

UNED

mdmsanchez@der.uned.es

Recepción: 22.11.2016. Revisión: 22.11.2016 Aceptación: 27.12.2016 Publicación 15.01.2017 
La editorial Síntesis ha creado la colección Ceremonial y protocolo cuya coordinadora soy. La Guía de protocolo y derecho premial civil forma parte de esta colección y su autora es $M^{\underline{a}}$ del Carmen Portugal Bueno, periodista y profesora en el máster en Protocolo de la UNED.

Tanto el estudiante como el profesional y los amantes del derecho premial español de carácter civil encontrarán en esta guía información sobre la historia de las órdenes y condecoraciones civiles de España, así como documentación sobre el ceremonial y la legislación de cada una de ellas. En resumen, se exponen las trece órdenes civiles que actualmente existen en España y las 27 condecoraciones españolas.

La singularidad de esta obra radica en el análisis de las órdenes y condecoraciones de las comunidades autónomas, tanto de sus gobiernos como de sus asambleas legislativas. Como explica la autora «es costumbre de la Administración pública el reconocer públicamente los méritos de las personas que han destacado por su servicio a la sociedad».

Otro aspecto original de la Guía de protocolo y derecho premial civil es la información sobre los honores y distinciones otorgados por los ayuntamientos, entidad que concede honores «con la finalidad de premiar especiales merecimientos, servicios extraordinarios y trabajos valiosos en diferentes ámbitos de la sociedad a la que gobiernan: cultura, ciencia, arte, deporte, economía, sociedad, política y profesión», indica su autora.

En definitiva, la Guía de protocolo y derecho premial ofrece información actualizada e histórica detallada sobre el derecho premial civil español a nivel nacional, autonómico y municipal.

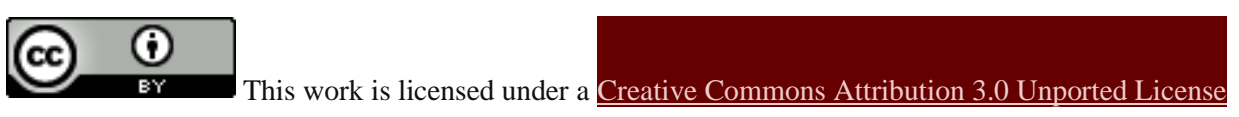

